\title{
When the forest dies: the response of forest soil fungi to a bark beetle-induced tree dieback
}

\author{
Martina Štursová ${ }^{1}$, Jaroslav Šnajdr¹, Tomáš Cajthaml ${ }^{1}$, Jiří Bárta ${ }^{2}$, Hana Šantrůčková ${ }^{2}$ \\ and Petr Baldrian ${ }^{1}$ \\ ${ }^{1}$ Institute of Microbiology of the ASCR, v.v.i., Vídeňská 1083, Praha 4, Czech Republic and ${ }^{2}$ Faculty \\ of Science, University of South Bohemia, České Budějovice, Czech Republic
}

\begin{abstract}
Coniferous forests cover extensive areas of the boreal and temperate zones. Owing to their primary production and $\mathrm{C}$ storage, they have an important role in the global carbon balance. Forest disturbances such as forest fires, windthrows or insect pest outbreaks have a substantial effect on the functioning of these ecosystems. Recent decades have seen an increase in the areas affected by disturbances in both North America and Europe, with indications that this increase is due to both local human activity and global climate change. Here we examine the structural and functional response of the litter and soil microbial community in a Picea abies forest to tree dieback following an invasion of the bark beetle Ips typographus, with a specific focus on the fungal community. The insect-induced disturbance rapidly and profoundly changed vegetation and nutrient availability by killing spruce trees so that the readily available root exudates were replaced by more recalcitrant, polymeric plant biomass components. Owing to the dramatic decrease in photosynthesis, the rate of decomposition processes in the ecosystem decreased as soon as the one-time litter input had been processed. The fungal community showed profound changes, including a decrease in biomass (2.5-fold in the litter and 12-fold in the soil) together with the disappearance of fungi symbiotic with tree roots and a relative increase in saprotrophic taxa. Within the latter group, successive changes reflected the changing availability of needle litter and woody debris. Bacterial biomass appeared to be either unaffected or increased after the disturbance, resulting in a substantial increase in the bacterial/fungal biomass ratio.
\end{abstract}

The ISME Journal (2014) 8, 1920-1931; doi:10.1038/ismej.2014.37; published online 27 March 2014

Subject Category: Microbial ecology and functional diversity of natural habitats

Keywords: fungi; disturbance; insect attack; decomposition; coniferous forests; root symbionts

\section{Introduction}

Northern coniferous forests cover extensive areas, including boreal forest biomes, as well as highaltitude montane regions and high-latitude temperate forests, providing a wide range of ecological and socio-economic services (Chapin et al., 2012). These forests have an important role in global carbon cycling, as they store substantial amounts of $\mathrm{C}$ in soil organic matter or biomass (Myneni et al., 2001; Ruckstuhl et al., 2008). Coniferous forests are viewed as an important global $\mathrm{C}$ sink (Bradshaw et al., 2009), and their functioning is thus potentially highly important for the global carbon balance as affected by climate change (Soja et al., 2007).

Forest disturbances are fundamental drivers of terrestrial carbon cycle dynamics (Adams et al., 2010). They can differ substantially in their extent

Correspondence: P Baldrian, Institute of Microbiology of the ASCR, v.v.i., Vídeňská 1083, 14220 Praha 4, Czech Republic.

E-mail: baldrian@biomed.cas.cz

Received 4 August 2013; revised 24 January 2014; accepted 10 February 2014; published online 27 March 2014 and nature, including the most severe events such as large-scale forest fires, windthrows or insect pest outbreaks. Such disturbances often have enormous impacts on the landscape and on ecosystem functioning. Outbreaks of phloem-feeding insects (for example, the bark beetle Ips typographus and the mountain pine beetle Dendroctonus ponderosae) reduce ecosystem productivity through tree mortality (Hicke et al., 2012) and may cause large forest areas in both North America and Europe to change from a sink to a substantial source of carbon (Okland and Bjornstad, 2006; Kurz et al., 2008).

Repeated large-scale insect-induced disturbances are historically documented (Schelhaas et al., 2003). However, recent evidence indicates that the frequency of these disturbances has tended to increase due to a combination of several factors. Changes in climate and hydrology, in combination with human influence on the size, structure and composition of forests or soil acidification, have all made forests more susceptible to insect attacks (Schelhaas et al., 2003; Breshears et al., 2009; Seidl et al., 2011).

Despite the recent focus on the study of forest disturbances in terms of $\mathrm{C}$ - and $\mathrm{N}$-cycle fluxes 
(Hartmann et al., 2012; Moore et al., 2013), other interesting aspects of these disruptive changes in ecosystem development continue to raise little research interest. This neglect also extends to the response of the soil microbial community, which has a substantial role in mediating the $\mathrm{C}$ and $\mathrm{N}$ cycles in the soil. Bark beetle attacks stop the flow of photosynthates to the soil via plant roots within one season, an effect that is comparable, to a considerable degree, to tree girdling. Girdling experiments have demonstrated that approximately one-half of the soil respiration in a coniferous forest is driven by photosynthate allocation belowground (Högberg et al., 2001). This process is largely mediated by ectomycorrhizal (ECM) fungi symbiotic with tree roots. In coniferous forests, these fungi represent up to one-third of total microbial biomass (Högberg and Högberg, 2002) and contribute significantly to the production and composition of dissolved organic carbon (DOC) and to $\mathrm{C}$ immobilization belowground (Clemmensen et al., 2013). Tree girdling thus decreases DOC production in soil by tens of percents (Giesler et al., 2007); at a later stage, ECM fungi disappear (Yarwood et al., 2009).

Field studies from areas of tree dieback produced by insect invasions also exhibit decreases in soil respiration as the result of the termination of photosynthate allocation (Moore et al., 2013). For this reason, it can be assumed that ECM fungi will disappear from disturbed forests, as demonstrated by girdling experiments. However, the extensive defoliation and the death of tree roots should increase the amount of substrate available for saprotrophic microorganisms, particularly fungi. These microorganisms may benefit from the newly available resources as well as from the decreased competition with ECM fungi, whose presence in the soil has been shown to decrease the rate of organic matter decomposition (Ekblad et al., 2013). It is important to investigate the possible substitution of saprotrophic taxa for ECM fungi in terms of abundance and the rate at which such a substitution can occur. An additional important area of investigation is the effect of the switch from photosynthatedriven to composition-driven soil functioning on nutrient availability in the ecosystem. All of this information can help us to understand the ecosystem-wide responses of forests to disturbances that represent a serious environmental concern.

The aim of this study was to describe the development of the size and structure of fungal communities in forest litter and soil after the disturbance of a coniferous forest represented by the invasion of the bark beetle I. typographus and to link these changes in the fungal communities with the changes observable in vegetation, soil and litter chemistry and decomposition. The bark beetle is endemic under stable conditions, but massive outbreaks occur under suitable climatic conditions following windthrow disturbances (Bouget and Duelli, 2004). Under such conditions, the bark beetle can cause a rapid defoliation of Norway spruce (Picea abies) followed by the dieback of all mature trees, often over very large areas (Okland and Bjornstad, 2006). Historically, Central Europe has experienced repeated bark beetle invasions (Svoboda et al., 2012). The recent massive spread of the bark beetle in the montane spruce forests of the Bohemian Forest following previous windthrows has allowed us to identify the area having a high probability of future bark beetle invasion and to obtain a time course of observations covering the most rapid stages of ecosystem development prior to and following the tree dieback.

The cessation of photosynthesis by trees should result in the disappearance of the ECM fungi associated with the tree roots unless the fungi temporarily switch to saprotrophic growth. We hypothesize that the release of inhibition by ECM fungi with the increased input of foliar and root litter promote the growth of saprotrophic fungi and result in higher enzyme activity in the years following a disturbance.

\section{Materials and methods}

Study area and sample collection

The study area was located at the highest altitudes $(1260-1300 \mathrm{~m})$ of the Bohemian Forest mountain range (Central Europe; $48^{\circ} 46.83 \mathrm{~N}, 13^{\circ} 50.38 \mathrm{E}$ ) and was originally covered by an unmanaged Norway spruce ( $P$. abies) forest. The mean annual temperature is $5.5^{\circ} \mathrm{C}$ and the mean annual precipitation is $1030 \mathrm{~mm}$. The bedrock is composed of granites, and the soil types in this area are primarily podzols with a thick layer of organic horizon (Kopáček et al., 2002). The area was chosen in the spring of 2008 for study because it was the last remaining healthy spruce stand in its general area. A future bark beetle (I. typographus) invasion from the surrounding areas and consequent tree dieback was considered highly probable.

The bark beetle outbreak occurred in July-August 2008. The outbreak caused the shedding of all tree foliage in August-September and the consequent dieback of all of the trees (Figure 1). To follow the mid-term effects of the disturbance without the potentially confounding effects of seasonal variation, sampling was conducted in late May during 2008-2012, approximately 1 month after snowmelt at the main study site (Site A). Three $4.5-\mathrm{cm}$ soil cores were collected from each of six plots $\left(4 \mathrm{~m}^{2}\right.$ each). Litter and organic soil horizon material were separately pooled for each plot. After the removal of the roots, litter material was cut into $0.5-\mathrm{cm}$ pieces and mixed; soil material was passed through 5-mm sterile mesh and mixed. Samples for DNA extraction were stored at $-80^{\circ} \mathrm{C}$ and those for chemical analyses at $-20^{\circ} \mathrm{C}$. Samples for enzyme assays were stored at $4^{\circ} \mathrm{C}$ and analyzed within $48 \mathrm{~h}$. Phospholipid fatty acid (PLFA) analyses were 


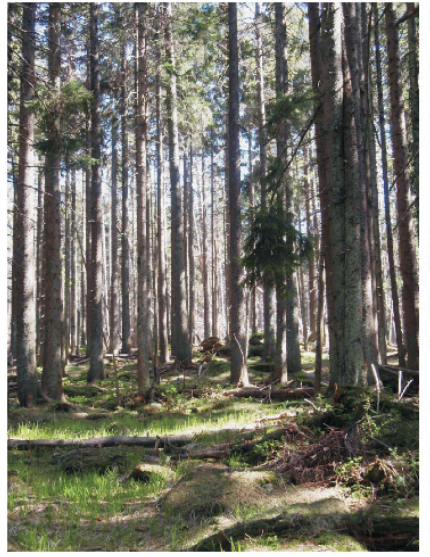

2008

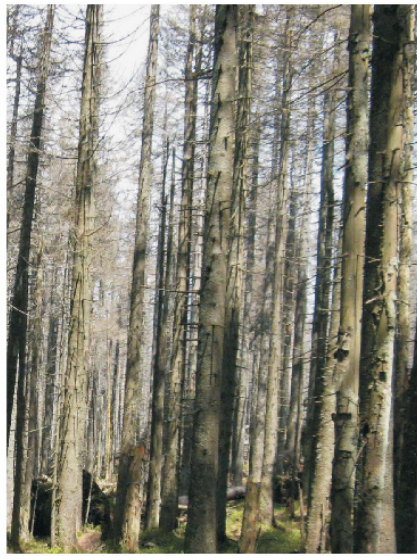

2010

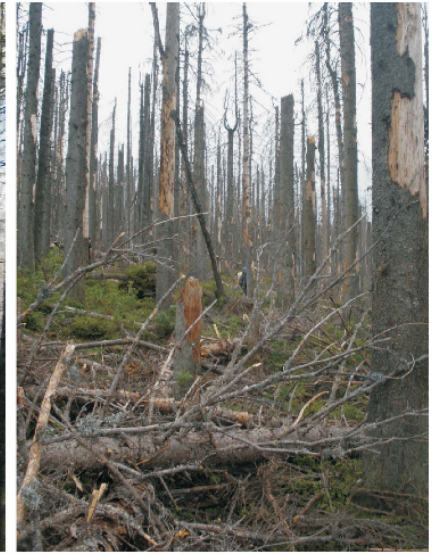

2012

Figure 1 Montane P. abies forest at Site A before (spring 2008) and after a tree dieback caused by a bark beetle invasion in summer 2008. After 2 years, the dead trees were still covered with bark and retained most of their branches (2010). Four years after the initial damage, much of the dead wood and bark had fallen to the ground (2012).

performed immediately on fresh samples. Additional study sites (Sites B and C) were sampled in May 2008, 2010 and 2012 to provide data from a larger area. The sampling was performed as described above and soil and litter samples were analyzed for microbial biomass content using PLFA and enzyme activity. Each of the study sites represented an area of $1-2 \mathrm{~km}^{2}$ to represent the bark beetle outbreak of the year 2008 that affected $\sim 60 \mathrm{~km}^{2}$. The estimate of the affected area and numbers of dead and live adult trees in the years 2007 and 2009 were calculated from aerial photos provided by the Czech Office for Surveying, Mapping and Cadastre (www.cuzk.cz).

\section{Soil analysis}

Dry mass content was measured after drying at $85^{\circ} \mathrm{C}$, and $\mathrm{pH}$ was measured in distilled water (1:10). The analysis of the chemical composition of litter and soil was performed as described previously (Šantrůčková et al., 2006). Briefly, available phosphorus $\left(\mathrm{PO}_{4}\right)$ was determined after extraction with oxalate, and water-extractable carbon (DOC) and nitrogen (DN) compounds were extracted from samples in cold water. The values of these components were determined on a TOC analyzer FormacsHT (Skalar, Breda, the Netherlands); the content of $\mathrm{NH}_{4}$ and $\mathrm{NO}_{3}^{-}$was measured using a flow injection analyzer Tecator 5042 (Foss, Hillerød, Denmark).

Enzyme assays for laccase, Mn-peroxidase, endocellulase, endoxylanase, $\beta$-glucosidase, $\alpha$-glucosidase, cellobiohydrolase, $\beta$-xylosidase, $\mathrm{N}$-acetylglucosaminidase (NAGase) and phosphatase were performed in soil homogenates (Štursová and Baldrian, 2011).

Microbial biomass was analyzed based on the PLFA content. PLFAs were extracted with chloroform-methanol-phosphate buffer and subjected to alkaline methanolysis, and free methyl esters were analyzed with GC-MS (Šnajdr et al., 2008). Fungal biomass was quantified based on $18: 2 \omega 6,9$ content, and bacterial biomass was quantified as the sum of bacteria-specific PLFAs (Bååth and Anderson, 2003).

\section{Amplicon pyrosequencing of fungal communities}

Total DNA was extracted from $250 \mathrm{mg}$ of litter or soil material using a method modified from SagovaMareckova et al. (2008); three samples per horizon and season were used. The extracted DNA was cleaned with a Geneclean Turbo Kit (MP Biomedicals, Solon, OH, USA). DNA yield and purity were checked with an ND1000 instrument (NanoDrop, Wilmington, DE, USA).

The primers ITS1/ITS4 (White et al., 1990) were used to amplify the ITS1 region, the 5.8S ribosomal DNA and the ITS2 region of the fungal ribosomal DNA. A two-step PCR amplification using composite primers containing multiplex identifiers (Baldrian et al., 2012) was performed to obtain amplicon libraries for 454-pyrosequencing. In the first step, each of three independent $25-\mu$ l reactions per DNA sample contained $2.5 \mu \mathrm{l}$ of $10 \times$ polymerase buffer, $1 \mu \mathrm{l}$ of each primer $(0.01 \mathrm{~mm}), 0.5 \mu \mathrm{l}$ of PCR Nucleotide Mix (10 mm) and $0.25 \mu$ l of polymerase $\left(2 \mathrm{U}_{\mu l}^{-1}\right.$; Pfu DNA polymerase:OmniTaq DNA polymerase, 1:24). The cycling conditions were $94{ }^{\circ} \mathrm{C}$ for $5 \mathrm{~min}$; 35 cycles of $94^{\circ} \mathrm{C}$ for $1 \mathrm{~min}$, $60{ }^{\circ} \mathrm{C}$ for $1 \mathrm{~min}$ and $70^{\circ} \mathrm{C}$ for $1 \mathrm{~min}$; followed by $70^{\circ} \mathrm{C}$ for $10 \mathrm{~min}$. The pooled PCR products were purified using a MinElute PCR Purification Kit (Quiagen, Hilden, Germany). The product of the first PCR was used as a template for the second PCR. In the second step, one 50- $\mu$ l reaction per DNA sample contained $5 \mu \mathrm{l}$ of $10 \times$ polymerase buffer, $1.5 \mu \mathrm{l}$ of dimethylsulphoxide for PCR, $0.4 \mu \mathrm{l}$ of forward fusion primer (ITS1, tag sequence, 454-specific sequence), $0.4 \mu \mathrm{l}$ of reverse fusion primer (ITS4, 454-specific sequence), 
$1 \mu \mathrm{l}$ of PCR Nucleotide Mix, $1.5 \mu \mathrm{l}$ of polymerase (2 $\mathrm{Ul}^{-1}$; Pfu DNA polymerase:Dynazyme DNA polymerase, 1:24) and $100 \mathrm{ng}$ of template DNA. The cycling conditions were $94{ }^{\circ} \mathrm{C}$ for $5 \mathrm{~min}$; 10 cycles of $94{ }^{\circ} \mathrm{C}$ for $1 \mathrm{~min}, 62^{\circ} \mathrm{C}$ for $1 \mathrm{~min}$ and $72{ }^{\circ} \mathrm{C}$ for $1 \mathrm{~min}$; followed by $70^{\circ} \mathrm{C}$ for $10 \mathrm{~min}$. PCR products were purified using Agencourt AMPure XP (Beckman Coulter, Beverly, MA, USA). The concentration of PCR products was quantified using the Qubit 2.0 Fluorometer (Life Technologies, Carlsbad, CA, USA), and an equimolar mix of PCR products from all samples was prepared. The mixture of PCR products was separated by electrophoresis and gel purified using the Wizard SV Gel and PCR Clean-Up System (Promega, Madison, WI, USA), followed by purification using Agencourt AMPure XP and a MinElute PCR Purification Kit to remove primerdimers. The amplicons were subjected to sequencing on a GS Junior sequencer (Roche, Basel, Switzerland).

\section{Bioinformatic analysis}

The pyrosequencing data were processed using the pipeline SEED 1.1.2 (Větrovský and Baldrian, 2013). Pyrosequencing noise reduction was performed using the Denoiser 0.851 (Reeder and Knight, 2010), and chimeric sequences were detected using Uclust 3.0 (Edgar et al., 2011) and deleted. Sequences shorter than 380 bases were removed. All remaining sequences were shortened to 380 bases and clustered using Usearch 5.2 (Edgar, 2010) at a $97 \%$ similarity level. Consensus sequences were constructed for each cluster, and the operational taxonomic units were constructed by clustering these consensus sequences at $97 \%$ identity (Lundberg et al., 2012). The closest hits were identified using the PlutoF pipeline (Tedersoo et al., 2010); non-fungal sequences $(<1 \%)$ were discarded. Sequence data have been deposited in the MG RAST public database (http://metagenomics.anl.gov/, data set number 4528531.3).

\section{Diversity and statistical analysis}

The Shannon-Wiener Index and the amount of the most abundant operational taxonomic units that represented $80 \%$ of all sequences were used as diversity estimates, providing combined information on species richness and evenness. These estimates were calculated for a data set containing 1000 randomly chosen sequences per sample. Because the abundances of sequences corresponding to fungal taxa varied widely, abundance data were normalized with a square root transformation and statistical analyses applied to these transformed data. Because the majority of taxa were represented by a very small number of reads and because such read counts have been demonstrated not to be technically reproducible (Lundberg et al., 2012), only the taxa with higher relative abundances $(\geqslant 0.5 \%$ in $\geqslant 3$ samples $)$ were tested for temporal changes in abundance and used in a principal component analysis along with the environmental variables. The pipeline SEED (see above) was used for data pre-processing and diversity calculations, and Statistica 7 (Statsoft, Tulsa, OK, USA) was used for statistical analyses. A one-way analysis of variance with a Fisher's least significant difference post hoc test was used to analyze the statistical significance of differences among groups of samples. Pearson correlation coefficients and $t$-values were calculated for linear regressions. Differences and correlations at $P<0.05$ were considered to be statistically significant.

\section{Results}

Ecosystem development following the bark beetle invasion

The bark beetle invasion occurred in July-August 2008 and the sampling at Site A thus covered the spring immediately preceding the event and four additional seasons after the event. The bark beetle invasion caused the shedding of all foliage in August-September 2008, resulting in the immediate termination of tree photosynthesis and followed by the dieback of all trees except small seedlings; such seedlings were rare in the study area (Figure 1). In the following years, the trees started to lose small twigs and bark. Later, beginning in the third year (2011), stem and root decay caused frequent windthrows and stem breaks induced by wind. This process caused deadwood to accumulate on the forest floor. Beginning in 2010, the loss of tree shading caused the gradual development of the understory, with increases in grasses (Deschampsia flexuosa, Calamagrostis sp.), bilberry (Vaccinium myrtillus) and fern cover and the increasing establishment of spruce seedlings (Figure 1). Owing to the loss of tree cover, maximal soil temperatures, especially in summer, were expected to increase, but the trend was insignificant due to high year-to-year variation. The soil temperatures before the late May sampling period were affected only slightly (data not shown). The moisture content did not show any consistent development, ranging from $74 \%$ to $77 \%$ in the litter and from $68 \%$ to $79 \%$ in the soil.

The massive input of litter in the autumn of 2008 and the cessation of photosynthetic $\mathrm{C}$ allocation following the tree dieback resulted in profound changes in litter and soil chemistry. In the litter, the highest DOC level was observed in the season following the heavy litterfall and then decreased by approximately one-half. Soil mineral nitrogen increased substantially but showed a 2-year delay after the dieback (Figure 2). In particular, nitrates increased in the litter from $3.1 \mu \mathrm{gg}^{-1}$ to $23-66 \mu \mathrm{gg}^{-1}$ and in the soil from $4.6 \mu \mathrm{gg}^{-1}$ to $16-36 \mu \mathrm{gg}^{-1}$. This increase was accompanied by a decrease in organic $\mathrm{N}$, which peaked in 2009 in both the soil and the 

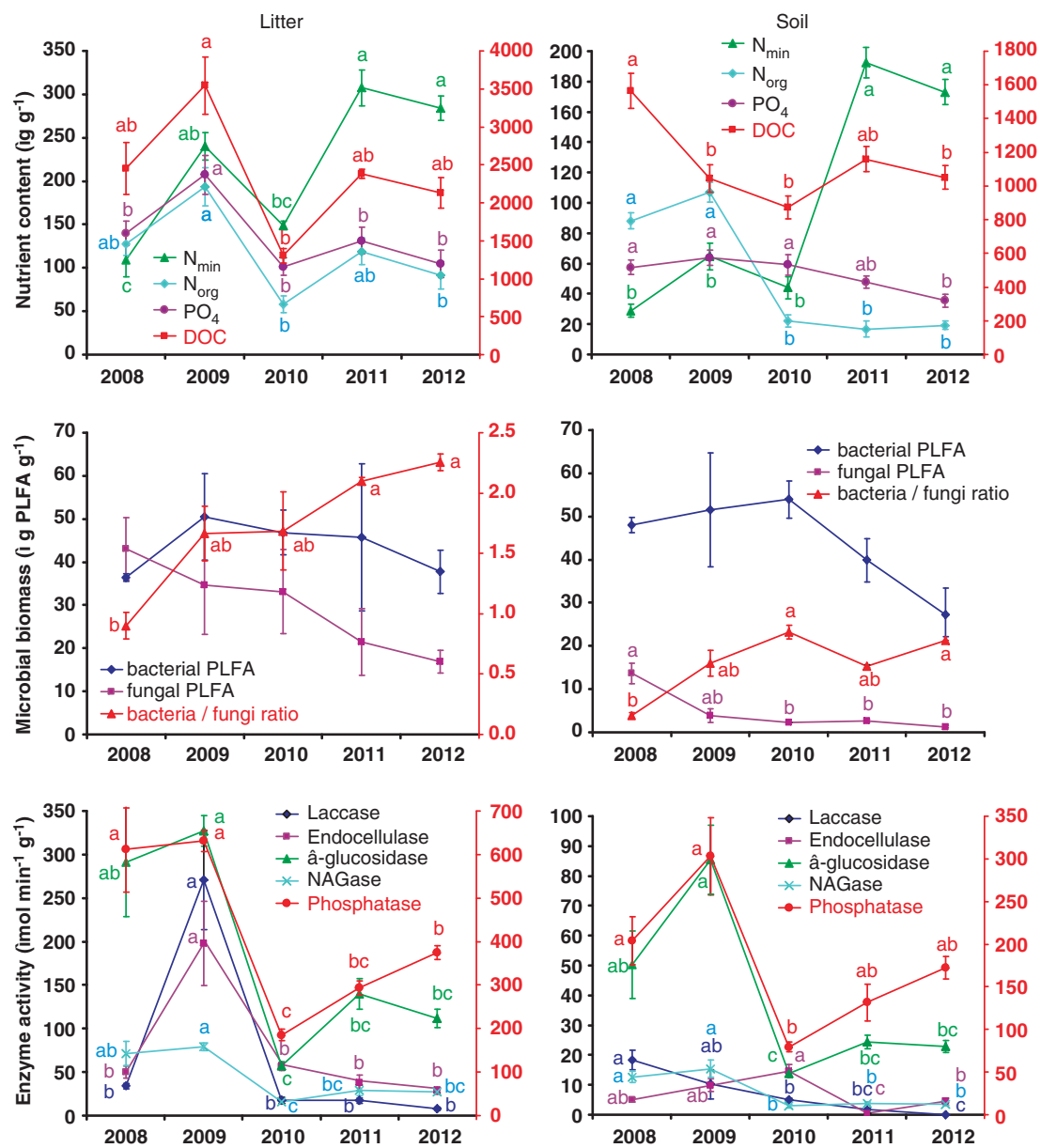

Figure 2 Nutrient composition, microbial biomass and enzyme activity in the litter and organic soil of a $P$. abies forest before and after a tree dieback caused by a bark beetle invasion. The data represent the means of three replicates with standard errors. Statistically significant differences among seasons are indicated by different letters. Right-hand axis displays variables indicated in red; abbreviations: $\mathrm{N}_{\min }-$ mineral $\mathrm{N}, \mathrm{N}_{\text {org }}$ - organic N, NAGase - N-acetylglucosaminidase.

litter. In both horizons, the $\mathrm{C} / \mathrm{N}$ ratio of the waterextractable compounds decreased from an initial 10-12 to 5-6 at the end of the study. Phosphates decreased significantly over time in both litter $(P=0.018)$ and soil $(P=0.044)$. Both litter and soil were strongly acidic, with mean $\mathrm{pH} 4.13 \pm 0.17$ for litter and $4.22 \pm 0.23$ for soil. No significant changes of $\mathrm{pH}$ in time were observed.

The total microbial biomass did not change significantly in the litter, whereas it decreased slightly over time in the soil $(P=0.021)$. Bacterial biomass did not show significant changes over the study period. Fungal PLFAs in the litter decreased significantly over time $(P=0.039)$, from $43 \mu \mathrm{gg}^{-1}$ before the tree dieback to $17 \mu \mathrm{g} \mathrm{g}^{-1}$ in 2012 , resulting in an increase in the bacterial/fungal biomass ratio ( $P=0.001$ ) from 0.9 to 2.3 . In the soil, fungal PLFAs also decreased significantly over time $(P=0.002)$. The PLFAs decreased from 17 to $4 \mu \mathrm{gg}^{-1}$ within 1 year and continued to decrease, reaching $1.3 \mu \mathrm{g} \mathrm{g}^{-1}$ in 2012; the bacterial/fungal biomass ratio increased six-fold ( $P=0.007$; Figure 2).

The activity of extracellular enzymes involved in decomposition exhibited two alternative patterns, which were similar in the litter and the soil. The enzymes decomposing starch ( $\alpha$-glucosidase), plant oligosaccharides ( $\beta$-glucosidase and $\beta$-xylosidase) and fungal biomass (NAGase), as well as exocellulase and phosphatase, were high just before and after the tree dieback and decreased to $20 \%-50 \%$ of these values in the next 3 years (Figure 2). Those enzymes involved in the decomposition of the more recalcitrant plant polymers, including crystalline cellulose (endocellulase), xylan (endoxylanase) and lignin (laccase and Mn-peroxidase), peaked 1 or 2 years after the tree dieback, and their activity also decreased in later years.

At a larger scale represented by all three study sites, the density of live trees dropped from $334 \pm 11 \mathrm{ha}^{-1}$ in 2007 to $1 \pm 1 \mathrm{ha}^{-1}$ in 2009 with a concurrent increase of dead tree densities from $13 \pm 4$ to $320 \pm 23 \mathrm{ha}^{-1}$. The difference of $27 \pm 9$ ha ${ }^{-1}$ trees represents those trees that fell down.

The trends in microbial biomass content and composition were generally in line with the observations at Site A. Most importantly, the fungal biomass content decreased either within 2 years after tree dieback (in soil) or within 4 years (in litter) 
while the total microbial biomass and bacterial biomass either remained unchanged or increased, depending on study site. This resulted in a decrease of fungal/bacterial biomass ratio (Supplementary Figure 1). Also the relative composition of the microbial community was consistent among the three study sites and clearly different among the years of sampling. In both the litter and soil, samples collected before tree dieback were separated from the later samples along the first PC1 axis, coinciding with the difference in the share of fungal biomass and activity of multiple extracellular enzymes. The effects of dry mass content and $\mathrm{pH}$ were both insignificant (Supplementary Figure 1). Except for phosphatase and endocellulase in the soil, all enzyme activities decreased during the 4 years following tree dieback (Supplementary Figure 1).

Response of the fungal community to the bark beetleinduced tree dieback

The fungal community in the stable spruce forest before the bark beetle invasion was species-rich. The diversity was similar among horizons, with a Shannon Index of $\sim 3.0$ at the sampling depth of 1000 sequences. Community evenness was low, with the top 10 operational taxonomic units representing $>60 \%$ of all sequences (Supplementary Tables 1 and 2). Neither diversity nor community evenness changed substantially during the following years. Typically, 15-35 operational taxonomic units represented the bulk of the sequences (80\%) in each sample. The initial litter community, however, exhibited a higher abundance of ascomycetes (40\%) and a lower abundance of the basidiomycetes (45\%) than the soil ( $25 \%$ and $58 \%$, respectively).

In addition to the abovementioned decrease in fungal biomass and the increase in the bacterial/ fungal biomass ratio, the composition of the fungal community also exhibited profound, successive changes following the tree dieback. In the litter, the initial community was primarily represented by sequences belonging to the basidiomycetous orders Atheliales (18\%), Cantharellales (8\%), Agaricales $(6 \%)$, Russulales $(6 \%)$, the ascomycetous order Helotiales (22\%) and the Mortierellomycotina $(14 \%)$ (Figure 3). Following the tree dieback, the community changed so that the Helotiales, Eurotiales and Agaricales represented the bulk of the community in 2009. In contrast, the orders including root symbiotic fungi decreased dramatically. These orders included the Cantharellales (2.4\%), Russulales $(0.9 \%)$, Telephorales $(0.4 \%)$ and Atheliales $(0.2 \%)$. In the subsequent three springs, the Agaricales and the Helotiales remained dominant, whereas purely ECM orders showed a further decrease. In 2011 and 2012, the sequences assigned to the order Lecanorales, comprising lichenized fungi, increased significantly to $4-9 \%$ (Figure 3).

In the soil, the initial community was dominated by the basidiomycetes, especially from the orders
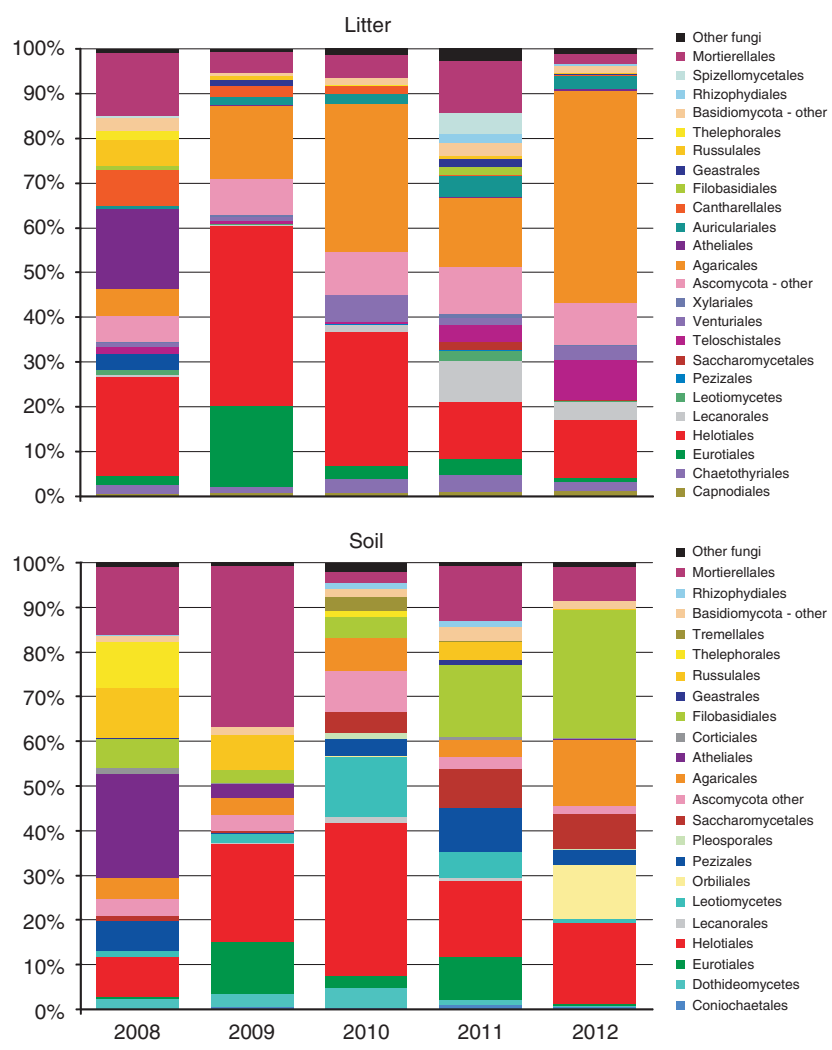

Figure 3 Phylogenetic assignment of fungal ITS sequences from a $P$. abies forest before and after a tree dieback caused by a bark beetle invasion. The data represent mean values from three study sites.

Atheliales, Russulales and Thelephorales, where ECM taxa prevail; ascomycetes were represented by the sequences of Helotiales and Pezizales; and Mortierellomycotina were also frequent (Figure 3). Within a year after the tree dieback, the abundance of the Basidiomycota decreased from $58 \%$ to $20 \%$, with concomitant increases in the Ascomycota (43\%) and Mortierellomycotina (36\%). Despite the tree dieback, the abundance of the ECM Russulales remained high. The abundance of the Ascomycota peaked at $76 \%$ in 2010 but later decreased with the establishment of the basidiomycetous saprotrophs of the orders Agaricales and Filobasidiales and also with the increase in the Mortierellomycotina. The ECM orders of Russulales, Thelephorales and Atheliales were virtually absent in 2012 .

The assignment of sequences to fungal genera allowed us to analyze the trends in the abundance of fungal ecophysiological groups. In the litter, saprotrophic taxa dominated throughout, but their dominance increased significantly after the tree dieback and reached $75-80 \%$. This increase was accompanied with a marked decrease in root symbiotic fungi, from $41 \%$ in the initial community to $<10 \%$ in the later years. The final years of observation saw an increase in lichen-forming fungi, whose sequences increased to $>10 \%$ of the total (Figure 4). On the level of individual genera, $58 \%$ of all taxa exhibited significant changes in sequence abundance. Four 

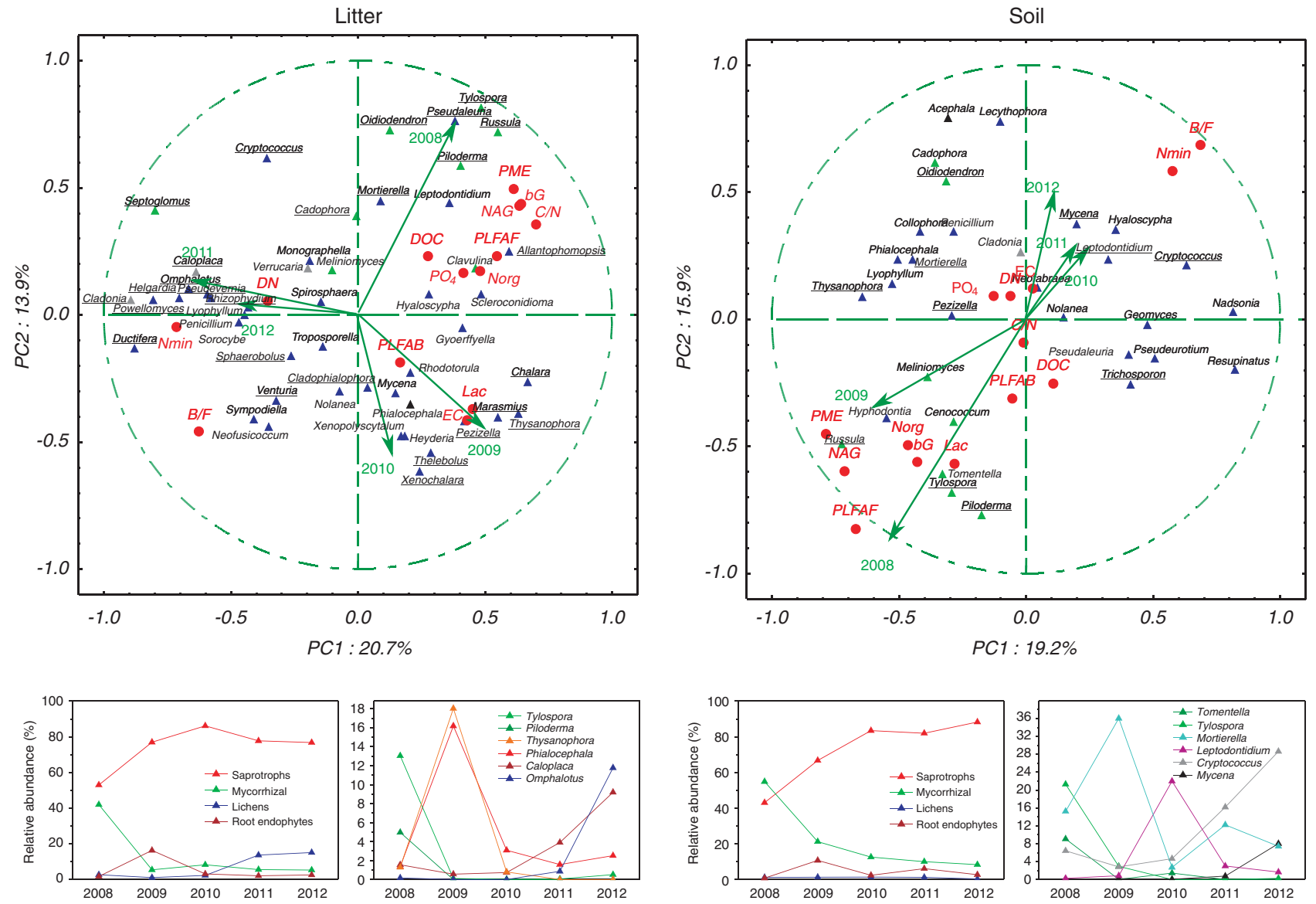

Figure 4 Principal component analysis of the relative abundances of fungal ITS sequences corresponding to dominant fungal genera in the litter and soil of a P. abies forest before and after a tree dieback caused by a bark beetle invasion. Sampling season loadings and environmental variables are indicated. All genera with $\geqslant 0.5 \%$ abundance in $\geqslant 3$ samples were considered. Fungal genera with significant differences in abundance among years are underlined. Root symbiotic fungi are indicated in green, root endophytes in black and lichens in gray. DN, dissolved N; C/N, C/N ratio; bG, $\beta$-glucosidase; EC, endocellulase; Lac, laccase; NAG, N-acetylglucosaminidase; PME, phosphatase; PLFAB, bacterial PLFA; PLFAF, fungal PLFA; B/F, bacterial/fungal biomass ratio. Bottom panels show relative abundances of ecophysiological groups of fungi and selected fungal genera; data represent means (standard errors omitted for clarity).

patterns of occurrence were evident. The abundance of the saprotrophic Mortierella and of Cadophora and Meliniomyces, mycorrhizal symbionts of bilberries, was steady over time but variable. The ECM genera Tylospora, Russula and Piloderma decreased more or less rapidly after the tree dieback. The abundance of the third group of fungi (for example, Thysanophora, Phialocephala, Chalara, Pezizella, Xenochalara and Powellomyces), peaked temporarily, earlier or later after the tree dieback. With the exception of the root endophyte Phialocephala, most of these fungi are saprotrophs. The final group of fungi tended to increase in the later years. This group included saprotrophs (Omphalotus, Venturia and Ductifera), lichen-forming fungi (Caloplaca, Cladonia and Pseudevernia) and an arbuscular mycorrhizal taxon (Septoglomus) (Figure 4, Supplementary Table 3).

In the soil, the increase in saprotrophs and decrease in root symbionts was relatively gradual. Nevertheless, the abundance of saprotroph sequences increased from $43 \%$ to $>85 \%$, whereas that of the root symbionts decreased from $58 \%$ to $<15 \%$ from 2008 to 2012 (Figure 4). The fungi whose sequence abundance did not show significant changes comprised saprotrophic taxa and the root symbionts of bilberries, Cadophora and Meliniomyces. ECM tree symbionts decreased with time, either immediately after the tree dieback (Tomentella, Tylospora and Piloderma) or later (Russula and Cenococcum). Certain saprotrophs (Thysanophora and Pezizella) and dark septate endophytes (Acephala and Phialocephala) peaked during the course of the ecosystem change, whereas the abundance of sequences of other saprotrophs, for example, Mycena and Cryptococcus, increased with time (Figure 4, Supplementary Table 3).

A principal components analysis showed a clear shift of the initial fungal community in the litter, from a high presence of ECM taxa to decomposerdominated communities in the early and later stages of post-disturbance development in 2009-2010 and 2011-2012, respectively. The seasons immediately before and after the tree dieback were characterized 
by high fungal biomass, a high content of DOC and organic $\mathrm{N}$ and a rapid decomposition of organic matter, whereas the late stages saw an increased abundance of bacteria and higher content of forms of mineral nitrogen (Figure 4). The fungal community composition in the soil in 2009 was similar, to a degree, to that in the undisturbed forest, with several of the ECM fungi still present. This composition was associated with high enzyme activity and the presence of organic N. In the following 3 years, the enzyme activity was substantially lower, and the bacterial/fungal biomass ratio was considerably higher. The inorganic forms dominated in the $\mathrm{N}$ pool. Root-associated fungi were largely replaced by saprotrophs (Figure 4).

\section{Discussion}

The tree dieback after insect invasion resulted in a complex transformation of the forest ecosystem; in this particular event, an area of $>60 \mathrm{~km}^{2}$ was affected. More than $84 \%$ living trees were killed by Ips sp. (represented in $95 \%$ byl I. typographus) in an area of $>5 \mathrm{~km}^{2}$ including all trees in and within $200 \mathrm{~m}$ of the Site A and the percentages were similar for the whole impacted area (Vacek and Krejčí, 2009). The tree cover of the pure spruce stands was reduced from $40 \%$ before the outbreak (typical for this ecosystem) to zero in late 2008; the abundance of spruce seedlings was $<1 \%$ (Anna Lepšová, unpublished data). The responses to disturbance comprised several levels of ecosystem properties including vegetation development, resource availability and chemistry. These complex changes were reflected in the level of decomposition processes, microbial abundance and community composition over time (Table 1). Although the data on fungal community composition were available only from a limited area of replicated plots within the study site A, the analysis of microbial biomass content and composition and enzyme activities at two additional sites indicate that the observed trends were consistent over a large area.

Tree dieback, as the primary result of the insect invasion, affected the ecosystem within one year, causing both the termination of photosynthesis and needle shedding. Needle litter represents the bulk of litterfall in P. abies forests. However, although the yearly input typically ranges between 400 and $700 \mathrm{~g} \mathrm{~m}^{-2}$, the bark beetle attack at a nearby site caused an input of $2.6 \mathrm{~kg} \mathrm{~m}^{-2}$ (Kaňa et al., 2013). Furthermore, although senescent needles have a C/ $\mathrm{N}$ ratio of 56 , fresh needles that are shed by infected trees have a $\mathrm{C} / \mathrm{N}$ ratio of 43 (Kopáček et al., 2010). This component represents a considerable input of organic matter available to litter-inhabiting decomposers. The input of dead organic matter from fine roots is another immediate - yet slightly slower result of tree dieback. The stock of $P$. abies fine roots $(<2 \mathrm{~mm})$ in Europe is reported to range from 50 to
$300 \mathrm{~g} \mathrm{~m}^{-2}$, with the estimated annual production/ mortality exceeding one-half of this standing pool (Brunner et al., 2013). Accordingly, the root litter input is substantially less than the needle input, and a one-time dieback would correspond to less than twice the mean annual input of root necromass.

As a response to the one-time litter input, the DOC content in the litter increased 1 year after the tree dieback. The DOC content in the soil decreased, and this change might be a result of the decreased photosynthate allocation. This finding is consistent with the decrease in DOC production in a spruce stand in the year following tree girdling (Ekberg et al., 2007). Over a longer time scale, tree dieback results in a prolonged decrease in photosynthate allocation belowground, as well as in the production of root and aboveground litter, because production by the trees cannot be offset by the productivity of the ground vegetation. Indeed, DOC and soil respiration were found to decrease in forests infested with mountain pine beetle within five years after a tree dieback (Moore et al., 2013). In the current study, we observed a decrease in decomposition, measured as the activity of extracellular enzymes, in the years following the dieback. The earlier decrease in the enzymes decomposing easily available substrate and the later activity of endolytic hydrolases of polysaccharides and ligninolytic enzymes indicates that enzyme activity is driven by the changing composition of the initial litter input. The same pattern can be observed during sequential decomposition of litter (Šnajdr et al., 2011a). The decrease in ligninolytic enzymes in the later stage could also be caused by the inhibitory effect of high $\mathrm{NO}_{3}^{-}$(Waldrop and Zak, 2006; Bárta et al., 2010).

Because chitin is a major component of fungal cell walls, the activity of chitinolytic NAGase has frequently been found to reflect contributions of fungal biomass to mycelial turnover and interspecific interactions (Šnajdr et al., 2008, 2011b). Higher chitinase levels have also been reported from soils containing ECM mycelial mats compared with nonmat soils (Kluber et al., 2011). In this case, the NAGase decrease most likely indicates a decrease in fungal biomass, especially that of the ECM fungi. Contrary to our expectations, the disappearance of ECM fungi did not lead to increased decomposition by the saprotrophic community. The reduction in competitive pressure from the ECM fungi thus appears to be less important than the combined effect of reduced litter and photosynthate allocation. As is the case for ligninolytic activity, the development of the fungal community could be inhibited by a high mineral $\mathrm{N}$ content, as documented in $\mathrm{N}$-saturated boreal forests (for example, Högberg et al., 2007). These results indicate that enzyme activity is driven primarily by the availability of easily decomposable compounds. These compounds were soon depleted, and the decrease in enzyme activity, along with fungal biomass, over time confirms the importance of fungi in decomposition. 
Table 1 Trends in the properties of a P. abies forest ecosystem during the four years following a tree dieback caused by a bark beetle invasion

\begin{tabular}{|c|c|}
\hline \multicolumn{2}{|l|}{ Vegetation } \\
\hline Old trees & Immediate dieback shortly after bark beetle invasion (Jonášová and Prach, 2004) \\
\hline Seedlings & Initially low, increase with time due to reduced shading, especially on deadwood (Jonášová and Prach, 200 \\
\hline Undergrowth & Initially low, increase with time due to reduced shading (Jonášová and Prach, 2008) \\
\hline \multicolumn{2}{|l|}{ Resources } \\
\hline Photosynthesis & $\begin{array}{l}\text { Tree photosynthetic allocation stops immediately after bark beetle invasion, initially low production of } \\
\text { undergrowth increases in time }\end{array}$ \\
\hline Leaf litter & Immediate increase in stock due to one-time litterfall during bark beetle invasion \\
\hline Root litter & Increase in stock due to tree dieback shortly after bark beetle invasion \\
\hline Woody litter & $\begin{array}{l}\text { Slow input of fine debris in the first } 2 \text { years (twigs, bark), rapid input of coarse wood since } 3 \text { years after tre } \\
\text { dieback }\end{array}$ \\
\hline \multicolumn{2}{|l|}{ Chemistry } \\
\hline Carbon & $\begin{array}{l}\text { Balance shifts rapidly from photosynthate-derived readily decomposable C to recalcitrant plant material } \\
\text { (litter, wood), no significant trends in DOC content }\end{array}$ \\
\hline Nitrogen & $\begin{array}{l}\text { No change in dissolved } \mathrm{N} \text {; organic } \mathrm{N} \text { decrease in soil since } 2 \text { years after tree dieback. Increase of inorganic } \\
\text { forms of } \mathrm{N}\left(\mathrm{NO}_{3}^{-} \text {in litter, } \mathrm{NH}_{4} \text { in soil) }\right.\end{array}$ \\
\hline Phosphorus & Decrease of $\mathrm{PO}_{4}$ \\
\hline Stoichiometry & $\mathrm{C} / \mathrm{N}$ decreases significantly in litter, marginally in soil \\
\hline Decomposition & Decomposition outweighs photosynthetic assimilation switching the ecosystem from a C-sink to C-source \\
\hline Soil respiration & $\begin{array}{l}\text { Predicted to decrease with decreased allocation of photosynthates belowground (Högberg et al., 2001; Moor } \\
\text { et al., 2013) }\end{array}$ \\
\hline Enzyme activity & Activity remains high in the year following tree dieback, substantial decrease afterwards \\
\hline Microbial biomass & No change in litter, slight decrease in soil \\
\hline Fungal community & Decrease of fungal biomass accompanied by the increase of bacterial/fungal biomass ratio \\
\hline Tree root symbionts & Most ECM fungi disappear within 1 year, only some persist longer \\
\hline Ericoid mycorrhiza & Present throughout \\
\hline Arbuscular mycorrhiza & Appearance in the late stage with the development of grass undergrowth \\
\hline Root endophytes & Present throughout, the increase in the year after dieback may be due to decomposition of dead roots \\
\hline Soil and litter saprotrophs & $\begin{array}{l}\text { Increase in relative abundance with time; their community Undergoes successional changes: early } \\
\text { decomposers are gradually replaced }\end{array}$ \\
\hline Wood decaying fungi & $\begin{array}{l}\text { Predicted to increase on deadwood, appearance in litter increases in the late stage with accumulating } \\
\text { deadwood }\end{array}$ \\
\hline Lichenized fungi & Relative abundance in litter increases with accumulating woody litter \\
\hline
\end{tabular}

In terms of the $\mathrm{C}$ balance in the entire ecosystem, it is important to note that tree dieback also terminates $\mathrm{C}$ storage via the accumulation of rootderived carbon immobilized in fungal mycelia. The importance of this process in deeper soil has recently been demonstrated (Clemmensen et al., 2013). Consequently, the $C$ storage potential of the ecosystem is expected to diminish.

The tree dieback also produced changes in the litter and soil $\mathrm{N}$ and $\mathrm{P}$ pools. Although the total nitrogen availability increased, as demonstrated by the decrease in the $\mathrm{C} / \mathrm{N}$ ratio of water-extractable compounds, organic $\mathrm{N}$ was soon replaced by mineral nitrogen compounds. This finding is consistent with observations of the increase in $\mathrm{NO}_{3}^{-}$and $\mathrm{NH}_{4}^{+}$in a range of soils two years after a bark beetle attack (Kaňa et al., 2013). The termination of photosynthate flow caused by the girdling of spruce trees was also found to increase microbial $\mathrm{N}$ mineralization in organic soil and increase the content of both ammonium and nitrate (Zeller et al., 2008). Finally, tree dieback in a nearby area also increased base saturation and decreased Al availability in topsoil (Kaňa et al., 2013). The extent of these changes and their effects on soil microorganisms, are, however, unclear.
The total microbial biomass in the litter did not show significant changes during the study period. On the basis of the mean estimate of the PLFA/ fungal biomass ratio (Baldrian et al., 2013), the fungal biomass in the litter decreased from $3.7 \mathrm{mgg}^{-1}$ to $1.5 \mathrm{mgg}^{-1}$, most likely due to the disappearance of ECM fungi. A more rapid and pronounced decrease in fungal biomass occurred in the soil, where fungal biomass decreased from the initial $1.2 \mathrm{mg} \mathrm{g}^{-1}$ to $0.11 \mathrm{mgg}^{-1}$. This result demonstrates the importance of photosynthate allocation for soil fungi. The extent of biomass decrease may indicate that, in addition to the ECM root symbionts, the photosynthates may also largely sustain the fungal soil saprotrophs. The same finding was recently reported from a deciduous forest, where photosynthate allocation during summer increased the biomass of both ECM and saprotrophic fungi (Voříšková et al., 2014). Bacterial biomass showed either no significant change or an increase (in the litter of Sites B and C), and the bacterial/fungal biomass ratio thus increased substantially, indicating the lesser dependence of bacteria on (or the lesser access to) photosynthate-derived C.

Fungal community composition responded to ecosystem disturbance in a complex way 
(Table 1). The ECM symbionts of tree roots disappeared either immediately (for example, Piloderma, Tylospora) or within the first 2-3 years. The long persistence of Cenococcum sequences in soil may be due to the persistence of its sclerotia. In contrast, the relatively high abundance of Russula sequences 2 years after tree dieback may be associated with its potential ability to grow saprotrophically. Because the fungus has been reported to harbor genes for exocellulase and lignin-degrading class II peroxidase (Bödeker et al., 2009; Štursová et al., 2012), it may be able to decompose the structural polymers of dead spruce roots. Because the mycelial mats of ECM fungi, for example, Piloderma, harbor a specific community of fungi and bacteria distinct from the non-mat soil (Kluber et al., 2011), the disappearance of ECM mats most likely affects a wider spectrum of other taxa. Although the ECM fungi disappeared, the genera Cadophora and Meliniomyces, forming ericoid mycorrhiza with the roots of bilberries and grasses, remained abundant because their plant hosts were not affected. The increased abundance of Septoglomus, an arbuscular mycorrhizal fungus, in the late phases could have been supported by the increasing grass cover but also by the decrease in phosphate availability.

Dark septate endophytes represent another group of fungi associated with roots, represented in this study primarily by the genera Phialocephala and Acephala. The ecology of dark septate endophytes is relatively less well known than that of other rootassociated fungi. The effects of DSEs on spruce range from neutral to negative and are straindependent (Tellenbach et al., 2011; Reininger et al., 2012). The relative increase in dark septate endophytes 1 year after the tree dieback may indicate their use of dead spruce roots as a substrate for growth. Phialocephala was also found in the roots of $D$. flexuosa (Tejesvi et al., 2013), a grass species that was found to increase in the disturbed area.

An apparent succession of individual saprotrophic fungal taxa was initiated by the massive initial input of litter during the bark beetle invasion (Figure 4). The genera Thysanophora and Chalara, which peaked 1 year after the forest disturbance, have been shown to inhabit spruce needles and to produce a broad range of enzymes acting on spruce litter, including endocellulase (Žifčáková et al., 2011). These genera are thus well suited for initial litter decomposition. Later phases were characterized by increases in the large cord-former Mycena and the yeast-like Cryptococcus, typical soil saprotrophs. The appearance of Omphalotus and Ductifera, primarily wood-associated saprotrophs, in the litter after 3 years had elapsed, had a clear connection with their spread through the environment from the decaying deadwood accumulating on the forest floor. The increase in the lichen-forming fungi Caloplaca, Cladonia and Pseudevernia most likely had a similar cause, although these fungi are also present in the litter of undisturbed spruce forests (Baldrian et al., 2012).

That substrate properties and fungal communities were similar in both litter and soil in the final 2 years may indicate that the extent of ecosystem change will gradually decrease. However, the process of forest regeneration after disturbance is only beginning, and further changes will follow. In the coming years, the decomposition of deadwood and of rhizodeposits of underground vegetation will be a major source of $\mathrm{C}$ in the ecosystem. It will also promote the establishment of spruce seedlings on decaying spruce logs, a process typical of this ecosystem (Bače et al., 2012) because seedling development on this substrate is not subject to competitive inhibition by undergrowth vegetation (Jonášová and Prach, 2004). The emergence of spruce seedlings will make the re-establishment of spruce ectomycorrhiza possible, although the ECM fungal biomass on young trees is initially low and has a specific composition (Wallander et al., 2010). Because the rate of ECM fungal development will be retarded by the high level of mineral $\mathrm{N}$ availability, saprotrophs will represent the dominant group of fungi, but only for a short period of several years.

This study demonstrates that an insect-induced disturbance of the forest ecosystem that rapidly and profoundly changed the vegetation cover and activity was also associated with profound changes in microbial community structure and activity, especially of soil fungi. The decrease in fungal biomass and the disappearance of fungi symbiotic with tree roots, as well as the successive changes in the saprotrophic fungal community, resulted from changes in nutrient availability. These changes occurred because readily available root exudates were replaced by more recalcitrant, polymeric plant biomass components. Owing to the dramatic decrease in photosynthesis, the rate of decomposition processes in the ecosystem decreased as soon as the one-time litter input was processed. Interestingly, the abundance of bacteria appeared to be unaffected or even increased following the disturbance.

\section{Conflict of Interest}

The authors declare no conflict of interest.

\section{Acknowledgements}

This work was supported by the Ministry of Education, Youth and Sports of the Czech Republic (LD12050), by the Czech Science Foundation (526/08/0751, P504/12/0709) and by the research concept of the Institute of Microbiology of the ASCR (RVO61388971). 


\section{References}

Adams HD, Macalady AK, Breshears DD, Allen CD, Stephenson NL, Saleska SR, Huxman TE, McDowell Ng. (2010). Climate-induced tree mortality: Earth system consequences. Eos, Trans Amer Geophys Union 91: 153-154.

Baldrian P, Kolařík M, Štursová M, Kopecký J, Valášková V, Větrovský $\mathrm{T}$ et al. (2012). Active and total microbial communities in forest soil are largely different and highly stratified during decomposition. ISME J 6: 248-258.

Baldrian P, Větrovský T, Cajthaml T, Dobiášová P, Petránková M, Šnajdr J et al. (2013). Estimation of fungal biomass in forest litter and soil. Fungal Ecol 6: $1-11$.

Bače R, Svoboda M, Pouska V, Janda P, Červenka J. (2012). Natural regeneration in Central-European subalpine spruce forests: which logs are suitable for seedling recruitment? Forest Ecol Manag 266: 254-262.

Bouget C, Duelli P. (2004). The effects of windthrow on forest insect communities: a literature review. Biol Conserv 118: 281-299.

Bradshaw CJ, Warkentin IG, Sodhi NS. (2009). Urgent preservation of boreal carbon stocks and biodiversity. Trends Ecol Evol 24: 541-548.

Breshears DD, Myers OB, Meyer CW, Barnes FJ, Zou CB, Allen CD et al. (2009). Tree die-off in response to global change-type drought: mortality insights from a decade of plant water potential measurements. Front Ecol Environ 7: 185-189.

Brunner I, Bakker MR, Bjork RG, Hirano Y, Lukac M, Aranda X et al. (2013). Fine-root turnover rates of European forests revisited: an analysis of data from sequential coring and ingrowth cores. Plant Soil 362: 357-372.

Bárta J, Applová M, Vaněk D, Krištůfková M, Šantrǔčková H. (2010). Effect of available P and phenolics on mineral N release in acidified spruce forest: connection with lignin-degrading enzymes and bacterial and fungal communities. Biogeochemistry 97: 71-87.

Bååth E, Anderson TH. (2003). Comparison of soil fungal/ bacterial ratios in a $\mathrm{pH}$ gradient using physiological and PLFA-based techniques. Soil Biol Biochem 35: 955-963.

Bödeker ITM, Nygren CMR, Taylor AFS, Olson A, Lindahl BD. (2009). ClassII peroxidase-encoding genes are present in a phylogenetically wide range of ectomycorrhizal fungi. ISME J 3: 1387-1395.

Chapin FS III, Matson PA, Vitousek P. (2012). Principles of Terrestrial Ecosystem Ecology. Springer Verlag: New York.

Clemmensen KE, Bahr A, Ovaskainen O, Dahlberg A, Ekblad A, Wallander $\mathrm{H}$ et al. (2013). Roots and associated fungi drive long-term carbon sequestration in boreal forest. Science 339: 1615-1618.

Edgar RC. (2010). Search and clustering orders of magnitude faster than BLAST. Bioinformatics 26: 2460-2461.

Edgar RC, Haas BJ, Clemente JC, Quince C, Knight R. (2011). UCHIME improves sensitivity and speed of chimera detection. Bioinformatics 27: 2194-2200.

Ekberg A, Buchmann N, Gleixner G. (2007). Rhizospheric influence on soil respiration and decomposition in a temperate Norway spruce stand. Soil Biol Biochem 39: 2103-2110.

Ekblad A, Wallander H, Godbold DL, Cruz C, Johnson D, Baldrian $\mathrm{P}$ et al. (2013). The production and turnover of extramatrical mycelium of ectomycorrhizal fungi in forest soils: role in carbon cycling. Plant Soil 366: 1-27.
Giesler R, Högberg MN, Strobel BW, Richter A, Nordgren A, Högberg P. (2007). Production of dissolved organic carbon and low-molecular weight organic acids in soil solution driven by recent tree photosynthate. Biogeochemistry 84: 1-12.

Hartmann M, Howes CG, VanInsberghe D, Yu H, Bachar D, Christen R et al. (2012). Significant and persistent impact of timber harvesting on soil microbial communities in Northern coniferous forests. ISME J 6: 2199-2218.

Hicke JA, Allen CD, Desai AR, Dietze MC, Hall RJ, Ted Hogg EH et al. (2012). Effects of biotic disturbances on forest carbon cycling in the United States and Canada. Global Change Biol 18: 7-34.

Högberg MN, Högberg P. (2002). Extramatrical ectomycorrhizal mycelium contributes one-third of microbial biomass and produces, together with associated roots, half the dissolved organic carbon in a forest soil. New Phytol 154: 791-795.

Högberg MN, Högberg P, Myrold DD. (2007). Is microbial community composition in boreal forest soils determined by $\mathrm{pH}, \mathrm{C}$-to-N ratio, the trees, or all three? Oecologia 150: 590-601.

Högberg P, Nordgren A, Buchmann N, Taylor AFS, Ekblad A, Högberg MN et al. (2001). Large-scale forest girdling shows that current photosynthesis drives soil respiration. Nature 411: 789-792.

Jonášová M, Prach K. (2004). Central-European mountain spruce (Picea abies (L.) Karst.) forests: regeneration of tree species after a bark beetle outbreak. Ecol Eng 23: 15-27.

Jonášová M, Prach K. (2008). The influence of bark beetles outbreak vs. salvage logging on ground layer vegetation in Central European mountain spruce forests. Biol Conserv 141: 1525-1535.

Kaňa J, Tahovská K, Kopáček J. (2013). Response of soil chemistry to forest dieback after bark beetle infestation. Biogeochemistry 113: 369-383.

Kluber LA, Smith JE, Myrold DD. (2011). Distinctive fungal and bacterial communities are associated with mats formed by ectomycorrhizal fungi. Soil Biol Biochem 43: 1042-1050.

Kopáček J, Cudlín P, Svoboda M, Chmelíková E, Kaňa J, Picek T. (2010). Composition of Norway spruce litter and foliage in atmospherically acidified and nitrogensaturated Bohemian Forest stands, Czech Republic. Boreal Environ Res 15: 413-426.

Kopáček J, Kaňa J, Šantrůčková H, Porcal P, Hejzlar J, Picek T et al. (2002). Physical, chemical, and biochemical characteristics of soils in watersheds of the Bohemian Forest lakes: I. Plešné Lake. Silva Gabreta 8: 43-62.

Kurz WA, Dymond CC, Stinson G, Rampley GJ, Neilson ET, Carroll AL et al. (2008). Mountain pine beetle and forest carbon feedback to climate change. Nature 452: 987-990.

Lundberg DS, Lebeis SL, Paredes SH, Yourstone S, Gehring J, Malfatti S et al. (2012). Defining the core Arabidopsis thaliana root microbiome. Nature 488: 86-90.

Moore DJP, Trahan NA, Wilkes P, Quaife T, Stephens BB, Elder K et al. (2013). Persistent reduced ecosystem respiration after insect disturbance in high elevation forests. Ecol Lett 16: 731-737.

Myneni RB, Dong J, Tucker CJ, Kaufmann RK, Kauppi PE, Liski J et al. (2001). A large carbon sink in the woody biomass of Northern forests. Proc Natl Acad Sci USA 98: 14784-14789. 
Okland B, Bjornstad ON. (2006). A resource-depletion model of forest insect outbreaks. Ecology 87: 283-290.

Reeder J, Knight R. (2010). Rapidly denoising pyrosequencing amplicon reads by exploiting rank-abundance distributions. Nat Methods 7: 668-669.

Reininger V, Grunig CR, Sieber TN. (2012). Host species and strain combination determine growth reduction of spruce and birch seedlings colonized by rootassociated dark septate endophytes. Environ Microbiol 14: 1064-1076.

Ruckstuhl KE, Johnson EA, Miyanishi K. (2008). Introduction. The boreal forest and global change. Phil Trans Royal Soc London Ser B 363: 2245-2249.

Sagova-Mareckova M, Cermak L, Novotna J, Plhackova K, Forstova J, Kopecky J. (2008). Innovative methods for soil DNA purification tested in soils with widely differing characteristics. Appl Environ Microbiol 74: 2902-2907.

Schelhaas MJ, Nabuurs GJ, Schuck A. (2003). Natural disturbances in the European forests in the 19th and 20th centuries. Global Change Biol 9: 1620-1633.

Seidl R, Schelhaas MJ, Lexer MJ. (2011). Unraveling the drivers of intensifying forest disturbance regimes in Europe. Global Change Biol 17: 2842-2852.

Soja AJ, Tchebakova NM, French NHF, Flannigan MD, Shugart HH, Stocks BJ et al. (2007). Climate-induced boreal forest change: predictions versus current observations. Glob Planet Change 56: 274-296.

Svoboda M, Janda P, Nagel TA, Fraver S, Rejzek J, Bace R. (2012). Disturbance history of an old-growth subalpine Picea abies stand in the Bohemian Forest, Czech Republic. J Veg Sci 23: 86-97.

Tedersoo L, Nilsson RH, Abarenkov K, Jairus T, Sadam A, Saar I et al. (2010). 454 Pyrosequencing and Sanger sequencing of tropical mycorrhizal fungi provide similar results but reveal substantial methodological biases. New Phytol 188: 291-301.

Tejesvi MV, Sauvola T, Pirttila AM, Ruotsalainen AL. (2013). Neighboring Deschampsia flexuosa and Trientalis europaea harbor contrasting root fungal endophytic communities. Mycorrhiza 23: 1-10.

Tellenbach C, Grunig CR, Sieber TN. (2011). Negative effects on survival and performance of Norway spruce seedlings colonized by dark septate root endophytes are primarily isolate-dependent. Environ Microbiol 13: $2508-2517$.

Vacek J, Krejčí F. (2009). Forest Ecosystems in the Bohemian Forest National Park (in Czech). Lesnická práce: Kostelec nad Černými Lesy, Czech Republic, pp 512.

Voříšková J, Brabcová V, Cajthaml T, Baldrian P. (2014). Seasonal dynamics of fungal communities in a temperate forest soil. New Phytol 201: 269-278.

Větrovský T, Baldrian P. (2013). Analysis of soil fungal communities by amplicon pyrosequencing: current approaches to data analysis and the introduction of the pipeline SEED. Biol Fertil Soils 49: 1027-1037.

Waldrop MP, Zak DR. (2006). Response of oxidative enzyme activities to nitrogen deposition affects soil concentrations of dissolved organic carbon. Ecosystems 9: 921-933.

Wallander H, Johansson U, Sterkenburg E, Brandström Durling M, Lindahl BD. (2010). Production of ectomycorrhizal mycelium peaks during canopy closure in Norway spruce forests. New Phytol 187: 1124-1134.

White TJ, Bruns T, Lee S, Taylor J. (1990). Amplification and direct sequencing of fungal ribosomal RNA genes for phylogenetics. In: Innins MA, Gelfand $\mathrm{DH}$, Sninsky JJ, White TJ (eds). PCR Protocols. Academic Press: San Diego, CA, pp 315-322.

Yarwood SA, Myrold DD, Högberg MN. (2009). Termination of belowground $\mathrm{C}$ allocation by trees alters soil fungal and bacterial communities in a boreal forest. FEMS Microbiol Ecol 70: 151-162.

Zeller B, Liu J, Buchmann N, Richter A. (2008). Tree girdling increases soil $\mathrm{N}$ mineralisation in two spruce stands. Soil Biol Biochem 40: 1155-1166.

Šantrůčková H, Krištůfková M, Vaněk D. (2006). Decomposition rate and nutrient release from plant litter of Norway spruce forest in the Bohemian Forest. Biologia 61: S499-S508.

Šnajdr J, Cajthaml T, Valášková V, Merhautová V, Petránková M, Spetz P et al. (2011a). Transformation of Quercus petraea litter: successive changes in litter chemistry are reflected in differential enzyme activity and changes in the microbial community composition. FEMS Microbiol Ecol 75: 291-303.

Šnajdr J, Dobiášová P, Větrovský T, Valášková V, Alawi A, Boddy L et al. (2011b). Saprotrophic basidiomycete mycelia and their interspecific interactions affect the spatial distribution of extracellular enzymes in soil. FEMS Microbiol Ecol 78: 80-90.

Šnajdr J, Valášková V, Merhautová V, Herinková J, Cajthaml T, Baldrian P. (2008). Spatial variability of enzyme activities and microbial biomass in the upper layers of Quercus petraea forest soil. Soil Biol Biochem 40: 2068-2075.

Štursová M, Baldrian P. (2011). Effects of soil properties and management on the activity of soil organic matter transforming enzymes and the quantification of soil-bound and free activity. Plant Soil 338: 99-110.

Štursová M, Žifčáková L, Leigh MB, Burgess R, Baldrian P. (2012). Cellulose utilization in forest litter and soil: identification of bacterial and fungal decomposers. FEMS Microbiol Ecol 80: 735-746.

Žifčáková L, Dobiášová P, Kolářová Z, Koukol O, Baldrian P. (2011). Enzyme activities of fungi associated with Picea abies needles. Fungal Ecol 4: 427-436.

Supplementary Information accompanies this paper on The ISME Journal website (http://www.nature.com/ismej) 